\title{
Primer registro, distribución y ecología de Diplophos proximus (Gonostomatidae, Teleostei) en el Pacífico colombiano.
}

\section{First record, distribution and ecology of Diplophos proximus (Gonostomatidae, Teleostei) in the Colombian Pacific.}

\author{
Beatriz Susana Beltrán-León ${ }^{1}$ and Raúl Ríos Herrera \\ $\begin{array}{ll}\text { (iD) } 0000-0002-4399-3642 & \text { (iD) } 0000-0002-3432-4076\end{array}$ \\ ${ }^{1}$ Investigadora en Ictioplancton y Estudios y Evaluación de Impacto Ambiental. Carrera 47 \# 2 A - 75 Apto 102 G. Cali, Colombia E-mail: \\ bbeltranleon@yahoo.com \\ ${ }^{2}$ Grupo de Investigación en Biodiversidad Neotropical, Inciva. Avenida Roosevelt \# 24 - 80.Cali, Colombia E-mail: raulriosh@gmail.com
}

\section{RESUMEN}

$\mathrm{S}$ e presentan los primeros hallazgos y distribución de larvas de la especie Diplophos proximus, familia Gonostomatidae, en el Pacífico de Colombia. Los análisis muestran larvas entre bahía Málaga y Tumaco (límites con Ecuador), con abundancias bajas durante las épocas de septiembre de 2003 y 2005, julio y diciembre de 2010, diciembre de 2013, febrero-marzo de 2014, junio de 2016 y junio y septiembre de 2017; siempre colectadas en estaciones ubicadas a más de $113 \mathrm{~km}$ de distancia de la costa y en los alrededores de la isla de Malpelo. Las larvas son alargadas y tienen notorios cambios durante el desarrollo, inicialmente ojos ovales, cuerpo poco pigmentado y sin fotóforos y finalmente ojos redondeados, pigmentos dorsales y en transformación presentan fotóforos. El presente trabajo contribuye con información de distribución y ecología de larvas de D. proximus, convirtiéndose en los primeros registros para el Pacífico colombiano, incluida la descripción de los estadios larvales encontrados.

PALABRAS CLAVE: Ictioplancton, Larvas, Aguas profundas, Pacífico colombiano.

\section{ABSTRACT}

$\mathrm{T}$ The first findings and distribution of larvae of the species Diplophos proximus, family Gonostomatidae, in the Pacific of Colombia are presented. The analyzes show larvae between Bahía Málaga and Tumaco (limits with Ecuador), with low abundances during the seasons of September 2003 and 2005, July and December 2010, December 2013, February-March 2014, June 2016 and June and September 2017, always collected at stations located more than $113 \mathrm{~km}$ away from the coast and around Malpelo island. The larvae are elongated and have noticeable changes during development, initially oval eyes, poorly pigmented body without photophores and finally rounded eyes, dorsal pigments and photophores during transformation. The present work contributes with information about distribution and ecology of larvae of D. proximus becoming the first records of catches for the Colombian Pacific, including the description of the larval stages found.

KEY WORDS: Ichthyoplankton, Gonostomatidae, Deep sea, Colombian Pacific.

DOI: 10.25268/bimc.invemar.2018.47.2.748 


\section{INTRODUCCIÓN}

Gonostomatidae es una familia de peces marinos abisales, conocidos comúnmente como peces luminosos; una familia relativamente pequeña que contiene únicamente ocho géneros y 32 especies. Sin embargo, compensan su baja diversidad genérica con su abundancia: Cyclothone, con 12 especies, es probablemente junto con Vinciguerria, el género de vertebrados más abundante del planeta. Se encuentran ampliamente distribuidos en todos los mares cálidos y templados del mundo, Atlántico, Índico y Pacífico (Nelson, 2006). Once especies de gonostomátidos existen en el área de CalCOFI (California Cooperative Oceanic Fisheries Investigations), pero sólo cuatro (Cyclothone acclinidens, C. signata, Diplophos taenia y Gonostoma atlanticum), se encuentran con cierta regularidad en las muestras de ictioplancton de dicha área. Otras cuatro (Cyclothone pseudopallida, Diplophos proximus, Gonostoma ebelingi y G. elongatum), aparecen principalmente fuera de la costa al sur de las estaciones CalCOFI; sus distribuciones al parecer son en gran parte fuera del área CalCOFI (Watson, 1966). Aunque en ocasiones Diplophos proximus Parr (1931) aparece como sinonimia de $D$. taenia, ambas especies son consideradas válidas según Ozawa et al. (1990).

Los gonostomátidos adultos son de tamaño pequeño (la mayoría $<7 \mathrm{~cm}$, máx. $36 \mathrm{~cm}$, normalmente $<$ $20 \mathrm{~cm}$ ), poseen ojos sésiles redondos u ovoides sin tejido coroides, dentición pequeña y finos radios branquiostegales. La bioluminiscencia es debida al desarrollo de fotóforos en tallas mayores de $7.5 \mathrm{~mm}$. Intestino de longitud variable, que termina en el origen de la aleta anal. Coloración generalmente negruzca, algunos son plateados. Son ovíparos; las larvas son alargadas y tienen notorios cambios durante el desarrollo, inicialmente ojos ovales, cuerpo poco pigmentado sin fotóforos y finalmente ojos redondeados, pigmentos dorsales y en transformación presentan fotóforos. Los adultos habitan principalmente profundidades medias entre los 300 y $800 \mathrm{~m}$ y algunas especies suben de noche a $50 \mathrm{~m}$ de la superficie. Se encuentran en las zonas epi (0$200 \mathrm{~m})$, meso $(200-1000 \mathrm{~m})$ y batipelágicas $(>1000 \mathrm{~m})$. Morfológicamente se parecen mucho a los phosíchthydos; el estado taxonómico de estas dos familias aún no ha sido resuelto del todo (Watson, 1996).

Según Ozawa et al. (1990), D. proximus, presenta diámetro orbital grande (en proporción al tamaño de la cabeza 21-28\%), comparado con las otras especies D. taenia, D. orientalis y D. australis (15-23\%). Sus características

\section{INTRODUCTION}

Gonostomatidae is a family of abyssal marine fish commonly known as luminous fish, this family is relatively small and contains only eight genera and thirtytwo species. However, the low generic diversity of these fish is compensated by their abundance. Cyclothone, which has twelve species, is considered one of the most abundant vertebrate genera on the planet along with Vinciguerria. These fish are widely distributed in all warm and temperate seas worldwide Atlantic, Indian, and Pacific oceans (Nelson, 2006). Eleven species of gonostomatids are observed in the CalCOFI area (California Cooperative Oceanic Fisheries Investigations), although only four (Cyclothone acclinidens, C. signata, Diplophos taenia and Gonostoma atlanticum) are found with some regularity in the ichthyoplankton samples from the CalCOFI area. Four other species (Cyclothone pseudopallida, Diplophos proximus, Gonostoma ebelingi and G. elongatum) appear mainly offshore south of the CalCOFI stations, and their distributions appear to be largely outside the CalCOFI area (Watson, 1966). Although D. proximus Parr (1931) sometimes appears as synonymous with $D$. taenia, both species are considered valid according to Ozawa et al. (1990).

Adult gonostomatids are small in size (most are $<$ $7 \mathrm{~cm}$, max $36 \mathrm{~cm}$, usually $<20 \mathrm{~cm}$ ), have round or ovoid sessile eyes without choroidal tissue, small dentition, and thin branchiostegal rays. The bioluminescence is due to the development of photophores in sizes bigger than $7.5 \mathrm{~mm}$. The fish have intestines of variable length that end at the origin of the anal fin and a generally blackish coloration, although some are silver. These fish are oviparous, and the larvae are elongated and present noticeable changes during development, with initially oval eyes, slightly pigmented bodies without photophores and finally rounded eyes, dorsal pigments and photophores present during transformation. The adults inhabit mainly intermediate depths between 300 and $800 \mathrm{~m}$, and some species rise at night to $50 \mathrm{~m}$ from the surface. These fish are found in the epi $(0-200 \mathrm{~m})$, meso (200-1000 m) and bathypelagic (> $1000 \mathrm{~m})$ zones. Morphologically, they are very similar to phosichthyids; however, the taxonomic status of these two families has not yet been fully resolved (Watson, 1996).

According to Ozawa et al. (1990), D. proximus presents a large orbital diameter (in proportion to the size of the head, 21-28\%) compared to the species D. taenia, 
diagnósticas son: 83-86 vértebras totales (TV), 33-35 abdominales $(\mathrm{AV})+49-52$ vértebras caudales $(\mathrm{CV})$ y 92100 fotóforos, suma de todas las series ventrales (IC).

El desove no se ha descrito para D. proximus, pero se ha documentado para otros gonostomátidos, los cuales son ovíparos, con huevos y larvas planctónicas. Las larvas de Diplophos presentan ojos no pigmentados, saco vitelino alargado y boca no funcional, el desarrollo es muy similar a otros gonostomátidos (Ahlstrom et al., 1984; Ozawa y Oda 1986).

Pocas larvas y pequeños juveniles pelágicos se han obtenido en recolecciones realizadas por CalCOFI desde el golfo de California y cerca del Cabo San Lucas. Sin embargo, son mucho más comunes al sur, frente a México y América Central. Para Colombia no se tienen registros de la captura ni de larvas ni de adultos de esta especie. Aparece citada en el artículo de Castellanos-Galindo et al. (2006) como una especie presente en aguas adyacentes al Pacífico colombiano.

Para esta región del Pacífico de Colombia se pueden encontrar las siguientes especies de gonostomátidos: Cyclothone acclinidens, C. microdon, C. signatha, Gonostoma sp. y Yarrella argenteola. Beltrán-León y Ríos (2000) realizaron los primeros registros en estadios larvales de Cyclothone acclinidens y C. signatha, citándolas para las subáreas III y IV y al oriente de la isla Malpelo, con abundancias bajas durante los cruceros de abril de 1993, junio-julio y diciembre de 1995 y noviembre de 1998. Por lo anterior, el presente trabajo contribuye con información de distribución y notas ecológicas de larvas de D. proximus, convirtiéndose en los primeros registros de capturas para el Pacífico colombiano, incluida la descripción de los estadios larvales encontrados.

\section{ÁREA DE ESTUDIO}

El Pacífico colombiano incluye las aguas comprendidas latitudinalmente entre las fronteras marítimas con Costa Rica, Panamá y Ecuador y longitudinalmente desde la línea de costa hasta el límite exterior de la zona económica exclusiva que genera la isla de Malpelo (740 km a partir de la costa continental), con $339500 \mathrm{~km}^{2}$ entre aguas estuarinas, costeras y oceánicas con profundidades hasta de 4000 m (Beltrán-León y Ríos, 2000).

Ubicado en el límite occidental del Pacífico Oriental, se caracteriza por la leve variación climática que se genera por su ubicación respecto al sol. La fisicoquímica
D. orientalis and D. australis (15-23\%). The diagnostic characteristics are 83-86 total vertebrae (TV), 33-35 abdominal vertebrae $(\mathrm{AV})+49-52$ caudal vertebrae $(\mathrm{CV})$, and 92-100 photophores, which is the sum of all ventral rows (IC).

Spawning has not been described for D. proximus, although it has been documented for other gonostomatids, which are oviparous, with eggs and planktonic larvae. The larvae of Diplophos present non-pigmented eyes, elongated yolk sacs and non-functional mouths, and the development is very similar to that of other gonostomatids (Ahlstrom et al., 1984: Ozawa and Oda 1986).

Few larvae and small pelagic juveniles have been found in the collections of CalCOFI from the Gulf of California and near Cabo San Lucas. However, they are much more common in the south, in front to Mexico and Central America. For Colombia, there are no catch records of larvae or adults of this species. Castellanos-Galindo et al. (2006) reported that this species is present in waters adjacent to the Colombian Pacific.

For this Pacific region of Colombia, the following species of gonostomatids can be found: Cyclothone acclinidens, C. microdon, C. signatha, Gonostoma sp. and Yarrella argenteola. Beltrán-León and Ríos (2000) were the first to record the larval stages of $C$. acclinidens and $C$. signatha, citing them for subareas III and IV and east of Malpelo Island, with low abundances during the research cruises of April 1993, June-July and December 1995 and November 1998. Therefore, this work contributes distribution information and ecological notes on $D$. proximus larvae, thus representing the first records of catches for the Colombian Pacific, including descriptions of the larval stages.

\section{STUDY AREA}

The Colombian Pacific includes the waters latitudinally between the maritime borders with Costa Rica, Panama and Ecuador and longitudinally from the coastline to the outer limit of the exclusive economic zone created by the island of Malpelo ( 400 miles from the continental coast). In total, $339500 \mathrm{~km}^{2}$ of water is considered, including estuarine, coastal and oceanic waters, which present depths of up to 4000 m (BeltránLeón and Ríos, 2000).

Located at the western limit of the Eastern Pacific, the Colombian Pacific is characterized by a slight climatic 
de las aguas depende en buena parte de los fenómenos locales como el movimiento de la Zona de Convergencia Intertropical (ZCIT), los drenajes dulceacuícolas continentales y el afloramiento en Panamá, como también de un complejo patrón de corrientes superficiales. Las principales corrientes que afectan las aguas del Pacífico colombiano son la ciclónica de Panamá, la de Colombia y la contracorriente Ecuatorial.

En términos generales se presenta un contraste entre las aguas oceánicas y las costeras, incluidas las estuarinas, especialmente hacia el sur de Cabo Corrientes. Las primeras presentan en la superficie temperaturas medias entre 25 y $27^{\circ} \mathrm{C}$ y salinidades medias de 33.5. Los valores extremos máximos de temperatura (hasta $31^{\circ} \mathrm{C}$ ) se han detectado con ocasión del fenómeno del Niño; mientras mínimos de hasta $18^{\circ} \mathrm{C}$ y salinidades cercanas a 35 se han registrado en los primeros meses del año y se deben al afloramiento del golfo de Panamá (Prahl et al., 1990). Para los estudios del Instituto Nacional de Pesca y Acuicultura -INPA, la zona fue estratificada por Zapata et al. (1998), en cuatro subáreas seleccionadas latitudinalmente de norte a sur según el tipo de costa, ancho de la plataforma, aporte de ríos y valores de temperatura y salinidad principalmente ((Figura 1). variation that is generated by its location with respect to the sun. Oceanographically, the physical chemistry of the waters depends largely on local phenomena, such as the movement of the Inter Tropical Convergence Zone (ITCZ), continental freshwater drainage, upwelling in Panama, and a complex pattern of surface currents. The main currents that affect the waters of the Colombian Pacific are the cyclonic currents of Panama and Colombia and the equatorial countercurrent.

In general terms, a contrast is observed between oceanic and coastal waters, including estuaries, especially towards the south of Cabo Corrientes. For example, the surface average temperatures vary between 25 and $27^{\circ} \mathrm{C}$, and the average salinity is 33.5. Maximum extreme temperatures (up to $31^{\circ} \mathrm{C}$ ) have been detected during El Niño events, while minimums of up to $18^{\circ} \mathrm{C}$ and salinities close to 35 have been recorded in the first months of the year because of the upwelling of the Gulf of Panama (Prahl et al., 1990). Studies by the Instituto Nacional de Pesca y Acuicultura (INPA) and Zapata et al. (1998) stratified the area into four sub-areas latitudinally from north to south according to the type of coast, width of the platform, contribution of rivers and values of temperature and salinity (Figure 1).

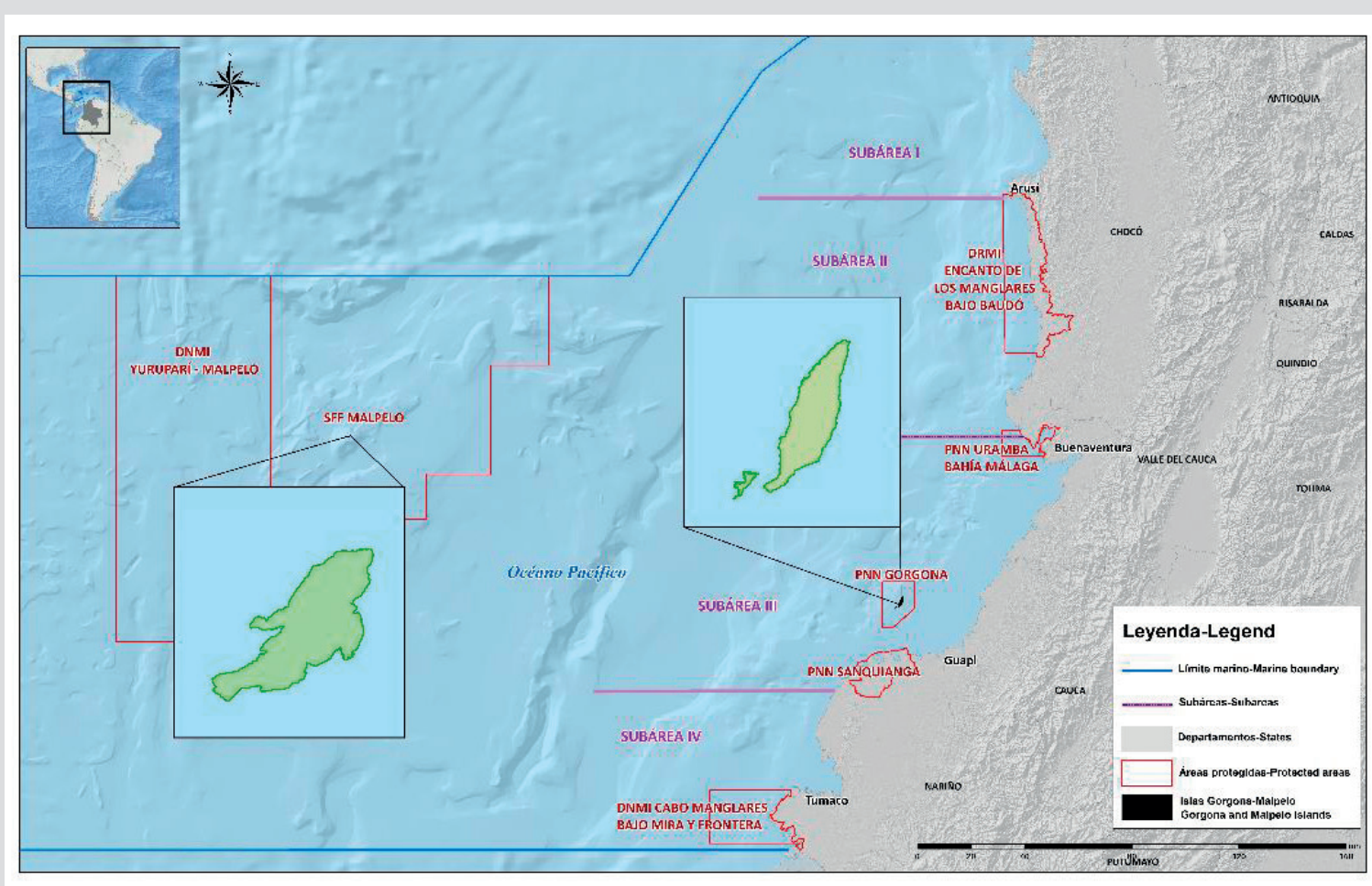


Subárea I: entre la frontera con Panamá y Cabo Corrientes $\left(07^{\circ} 13^{\prime}\right.$ Lat. N - $05^{\circ} 30^{\prime}$ Lat. N). Altamente influenciada por la surgencia de Panamá, zona de alta pluviosidad, con poca influencia de ríos, plataforma estrecha más o menos de 1.8 a $3.7 \mathrm{~km}$ y sustrato rocoso en el fondo.

Subárea II: entre Cabo Corrientes y bahía Málaga $\left(05^{\circ} 30^{\prime}\right.$ Lat. $\mathrm{N}-04^{\circ} 00^{\prime}$ Lat. N). La plataforma, más ancha que la anterior, variando entre 9 y $19 \mathrm{~km}$, recibe mayor influencia de ríos que en la subárea I, especialmente debido al gran aporte de agua dulce del río San Juan y posee generalmente sustrato areno fangoso en el fondo.

Subárea III: entre bahía Málaga y Pasacaballos $\left(04^{\circ} 00^{\prime}\right.$ Lat. $\mathrm{N}-02^{\circ} 30^{\prime}$ Lat. N). Este sector tiene mayor aporte de agua dulce que las dos anteriores por la gran cantidad de ríos, su plataforma es bastante extensa llegando a 56 o $74 \mathrm{~km}$ y con sustrato areno fangoso.

Esta subárea se caracteriza por ser una zona de convergencia de flujos costeros, bien sea de origen oceánico, de mareas o fluviales. Por su amplia plataforma y la ubicación geográfica, las mezclas de agua son más evidentes y duraderas que en las otras subáreas del litoral.

En general, la disposición superficial de los parámetrosvoceanográficos describe la época de final de año como de enfriamiento estacional por las temperaturas superficiales más bajas $\left(\bar{x}=26^{\circ} \mathrm{C}\right)$ (noviembre y diciembre); contrarias a las mayores temperaturas detectadas a mediados de año $\left(\bar{x}=28^{\circ} \mathrm{C}\right)$ (mayo y julio). La salinidad superficial es menor durante las épocas húmedas o de invierno $(\bar{x}=20-29)$ (mayo y noviembre) y el oxígeno es la variable más homogénea, presentando el valor promedio más alto durante julio $(4 \mathrm{ml} / \mathrm{l})$.

Subárea IV: localizada entre Pasacaballos y frontera con Ecuador (02 $30^{\prime}$ Lat. N - 01 $30^{\prime}$ Lat. N). Su gran aporte de agua dulce proviene de los ríos Patía y Mira, su plataforma es muy angosta, variando entre 9 y $19 \mathrm{~km}$ y tiene sustrato areno fangoso.

Se halla más influenciada por aguas oceánicas y ecuatoriales (propias de la contracorriente ecuatorial). Por este motivo la caracterización oceanográfica consiste en presentar aguas más frías $\left(27.4-27.6^{\circ} \mathrm{C}\right)$ e hialinas (31-34) que las ubicadas al norte bajo una mayor influencia costera y pluviométrica. Esta situación es independiente de la época anual, y es la intensidad de los vientos alisios, lo que permite que dicha contracorriente tenga más o menos alcance en la costa colombiana.
Subarea I: between the border with Panama and Cabo Corrientes $\left(07^{\circ} 13^{\prime}\right.$ Lat. N - $05^{\circ} 30^{\prime}$ Lat. N). This area is highly influenced by the upwelling of Panama, has high rainfall, little influence of rivers, a narrow platform of approximately 1.8 to $3.7 \mathrm{~km}$ and a rocky substrate on the bottom.

Subarea II: between Cabo Corrientes and Málaga Bay $\left(05^{\circ} 30^{\prime}\right.$ Lat. $\mathrm{N}-04^{\circ} 00^{\prime}$ Lat. N). This area has a platform that is wider than the previous and varies between 9 and $19 \mathrm{~km}$, and it receives greater influence from rivers than subarea I, especially due to the large supply of fresh water from the San Juan River, and generally has a muddy sandy substrate on the bottom.

Subarea III: between Málaga Bay and Pasacaballos $\left(04^{\circ} 00^{\prime}\right.$ Lat. $\mathrm{N}-02^{\circ} 30^{\prime}$ Lat. $\left.\mathrm{N}\right)$. This sector has a greater freshwater contribution than the previous two because of the large number of rivers, and its shelf is quite extensive, reaching 56 or $74 \mathrm{~km}$, and it has a sandy mud substrate.

This subarea is characterized as a zone of convergence of coastal flows, whether of oceanic, tidal or fluvial origin. Due to its wide platform and geographical location, water mixing is more evident and longer-lasting than in the other sub-areas of the coast.

In general, the surface arrangement of the oceanographic parameters describes the end-of-year season as seasonal cooling due to the lower surface temperatures $\left(\bar{x}=26^{\circ} \mathrm{C}\right)$ (November and December), which is in contrast to the higher temperatures detected at mid-year $\left(\bar{x}=28^{\circ} \mathrm{C}\right)$ (May and July). The surface salinity is lower during the rainy seasons ( $\bar{x}=20-29$ ) (May and November), and oxygen is the most homogeneous variable, presenting the highest average value during July $(4 \mathrm{ml} / \mathrm{l})$.

Subarea IV: located between Pasacaballos and the border with Ecuador $\left(02^{\circ} 30^{\prime}\right.$ Lat. N - 01 $30^{\prime}$ Lat. N). The great contribution of fresh water in this area comes from the Patía and Mira rivers, its platform is very narrow and varies between 9 and $19 \mathrm{~km}$, and it has a sandy muddy substrate.

This area is more influenced by oceanic and equatorial waters (typical of the equatorial countercurrent). For this reason, the oceanographic characterization consists of waters that are colder $\left(27.4-27.6^{\circ} \mathrm{C}\right)$ and more hyaline (31-34) than the waters to the north, which are under greater coastal and pluviometric influence. This situation is independent of the annual season, and the intensity of the trade winds allows this countercurrent to reach our coast. 
Según Zapata et al. (1998), la importancia del Pacífico colombiano está representada por ser el punto de confluencia de variados elementos de la fauna submarina de interés zoogeográfico pertenecientes a diferentes provincias como la Indo-Pacífica, Caribe, Golfo de California y PeruanoChilena, además de los de distribución circumtropical o cosmopolitas. Estas aguas reflejan en su composición faunística no solo la dinámica actual sino también la de un remoto pasado geológico, aún poco conocido.

\section{MATERIALES Y MÉTODOS}

El presente trabajo se realizó con 24 muestras positivas para larvas de la especie, obtenidas durante nueve cruceros: dos cruceros ERFEN (Estudio Regional Fenómeno de "El Niño"), los cuales se realizaron en toda el área del Pacífico colombiano durante los septiembres de 2003 y 2005 y otros siete cruceros realizados en la línea recta entre Buenaventura y el Santuario de Fauna y Flora Malpelo durante julio y diciembre de 2010, diciembre de 2013, febrero-marzo de 2014, junio de 2016, junio y septiembre de 2017, incluidas estaciones alrededor de la isla. El muestreo de ictioplancton y oceanografía se realizó a lo largo de 10 transectos perpendiculares a la costa, paralelos entre sí y separados $54 \mathrm{~km}$, con 42 estaciones para los cruceros ERFEN de 2003 y 2005 (Figura 2) y 20 estaciones, ocho en línea recta entre Buenaventura y Malpelo y seis estaciones diurnas y nocturnas alrededor de la isla durante 2010 y 2017 (Figura 3).

Las muestras se obtuvieron mediante el empleo de una red bongo estándar de $60 \mathrm{~cm}$ de diámetro en cada una de las bocas, provista de mallas de 300 y 500 micrómetros, copos colectores blandos y contadores de flujo análogos Hydrobios (Figura 4), efectuando arrastres oblicuos de acuerdo con la metodología establecida por Smith y Richardson (1979), hasta una profundidad máxima de 200 $\mathrm{m}$. Las muestras se fijaron con formol neutralizado con bórax, al 10\% en agua de mar. En la Figura 5, se observan las estaciones donde fueron capturadas las larvas.

La identificación de las larvas de D. proximus se realizó tomando como base los caracteres determinantes de merística, morfometría y pigmentación, establecidos en el Atlas No. 33 de CALCOFI (Moser, 1996). Para determinar la abundancia se consideró el número de larvas y post larvas capturadas por familia, tipo, género, especie y se estandarizaron los resultados a número de individuos por $10 \mathrm{~m}^{2}$, para el análisis se siguió el rango establecido por Rueda y Beltrán (1992): Baja: 1 - 99 individuos/10m²; Media: 100 - 499 individuos $/ 10 \mathrm{~m}^{2}$; Alta:
According to Zapata et al. (1998), the importance of the Colombian Pacific is related to its position as a point of confluence of various elements of the underwater fauna of zoogeographic interest that belong to different provinces such as Indo-Pacific, Caribbean, Gulf of California and Peruvian-Chilean, in addition to those of circumtropical distribution. The faunal composition of these waters reflects not only the current dynamics but also the remote geological past, which is still largely unknown.

\section{MATERIALS AND METHODS}

The present work was carried out with 24 positive samples for larvae of the species, which were obtained during nine cruises: two ERFEN cruises ("El Niño" Regional Phenomenon Study), which were carried out throughout the Colombian Pacific area in September 2003 and 2005; and seven other cruises performed in a straight line between Buenaventura and the Malpelo Fauna and Flora Sanctuary (including stations around the island) in July and December 2010, December 2013, February-March 2014, June 2016 and June and September 2017. Ichthyoplankton sampling and oceanographic measurements were performed along 10 transects that were perpendicular to the coast, parallel to each other and $54 \mathrm{~km}$ apart, with 42 stations for the ERFEN cruises of 2003 and 2005 (Figure 2) and 20 stations for the Buenaventura and the Malpelo Fauna and Flora Sanctuary cruises, with eight in a straight line between Buenaventura and Malpelo and six diurnal and nocturnal stations around the island during 2010 and 2017 (Figure 3).

Samples were obtained by a standard bongo net (60 $\mathrm{cm}$ diameter), with a mesh of 300 and 500 microns, soft cod-end collectors and Hydrobios flow meters (Figure 4). Oblique trawls were performed according to the methodology established by Smith and Richardson (1979) up to a maximum depth of $200 \mathrm{~m}$. The samples were fixed with formalin neutralized with borax at $10 \%$ in seawater. The stations where larvae were captured are shown in Figure 5.

The identification of $D$. proximus larvae was carried out based on the determining meristic, morphometric and pigment characteristics as established in Atlas No. 33 of CalCOFI (Moser, 1996). To determine abundance, the number of larvae and post larvae captured by family, type, genus, and species was considered and the results were standardized to a number of individuals per $10 \mathrm{~m}^{2}$, and for the analysis, the range established by Rueda and Beltrán (1992) was followed: Low: 1 - 99 individuals/10 m²; Medium: 100 - 499 individuals/10 
$>500$ individuos $/ 10 \mathrm{~m}^{2}$. El análisis global de la información permitió elaborar dibujos con una cámara lúcida Wild, de cada uno de los estadios de la especie donde se presentan las diferentes características asociadas a una talla determinada. $\mathrm{m}^{2}$; High: $>500$ individuals $/ 10 \mathrm{~m}^{2}$. The global analysis of the information allowed drawings to be created with a Wild lucid camera, for each of the stages of the species where the different characteristics associated with a given size are presented.

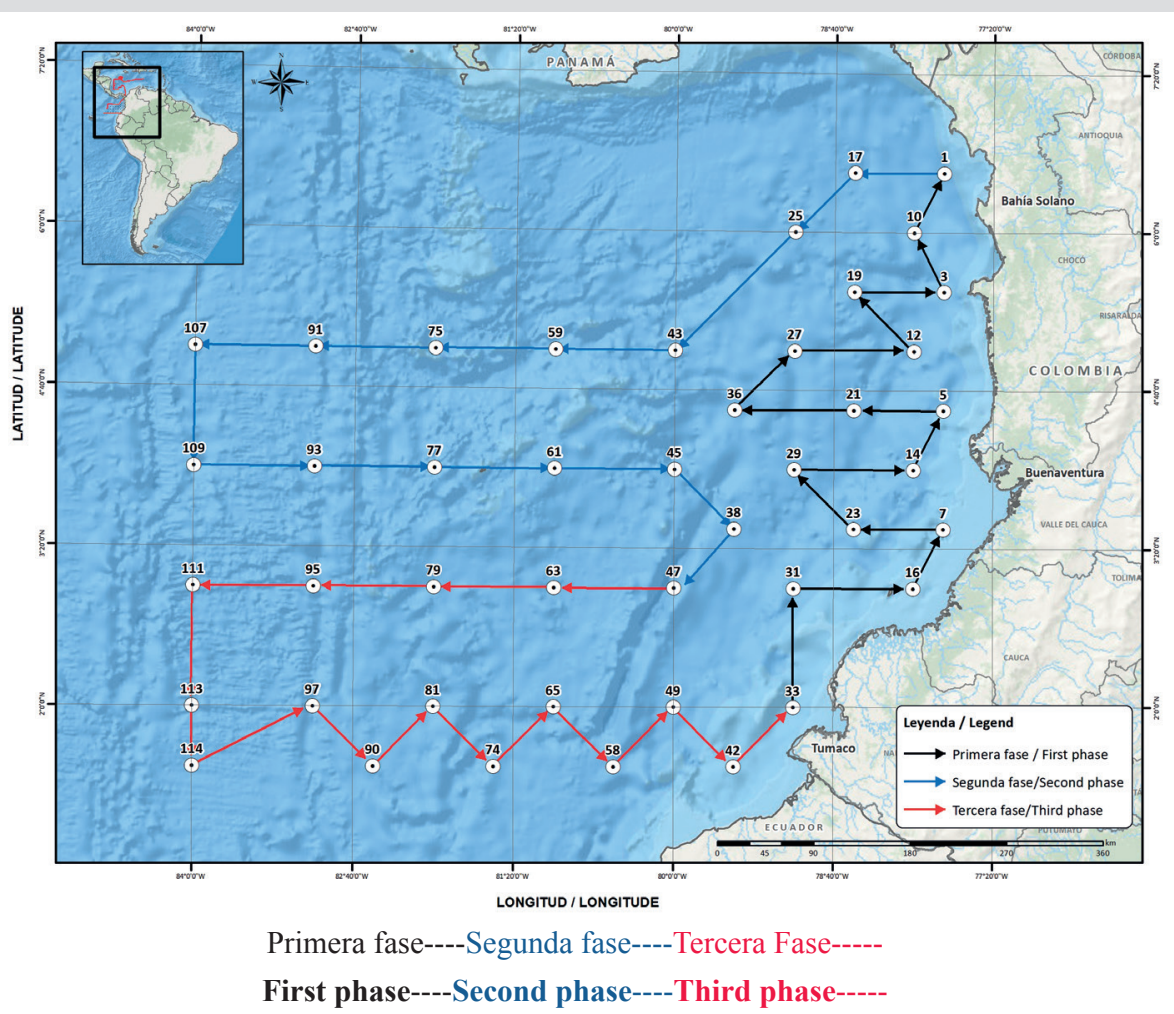

Figura 2. Estaciones y ruta de muestreo Cuenca del Pacíico Cruceros ERFEN 2003 y 2005 (Tomado de CCCP 2004-2007 Planes de ejecución Cruceros ERFEN).
Figure 2. Stations and sampling route of the Cuenca del Pacífico ERFEN cruices 2003 and 2005 (Taken from the CCCP 2004-2007 Cruise Project Execution Plans, ERFEN).

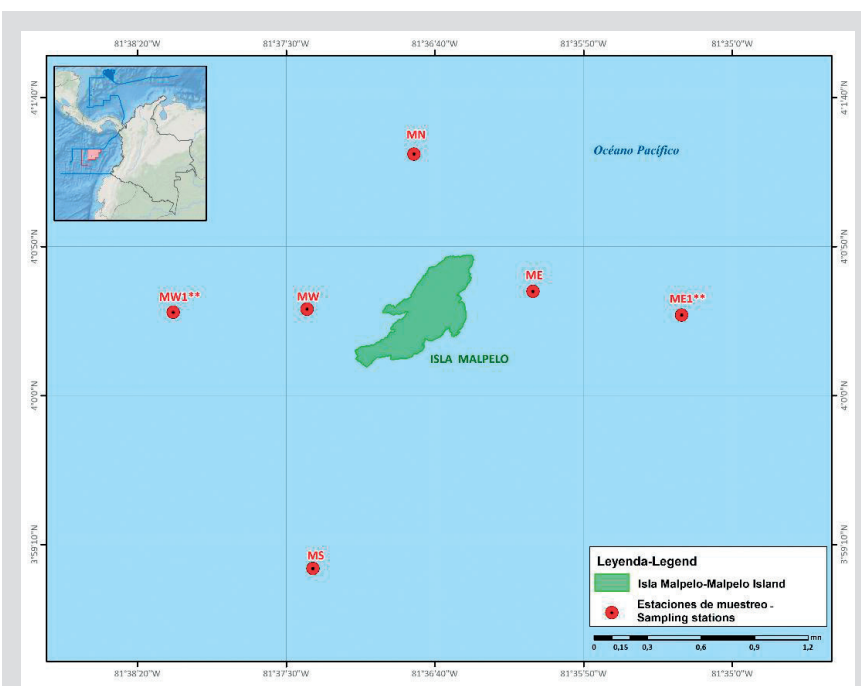

Figura 3. Estaciones de muestreo en el Santuario de Fauna y Flora Malpelo y el trayecto costa-Malpelo.

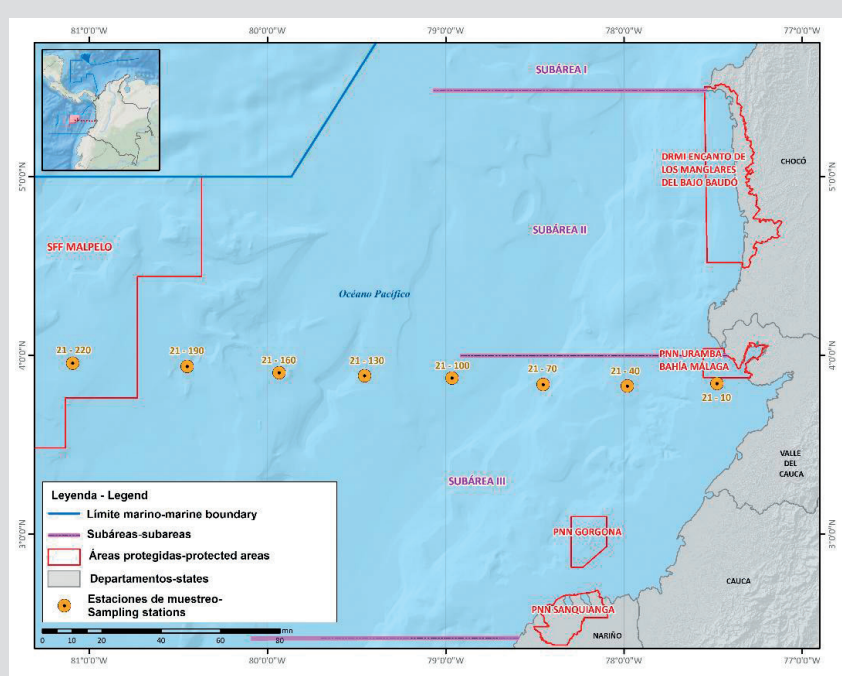

Figure 3. Sampling stations in the Wildlife and Flora Sanctuary Malpelo and the coastal- Malpelo route. 


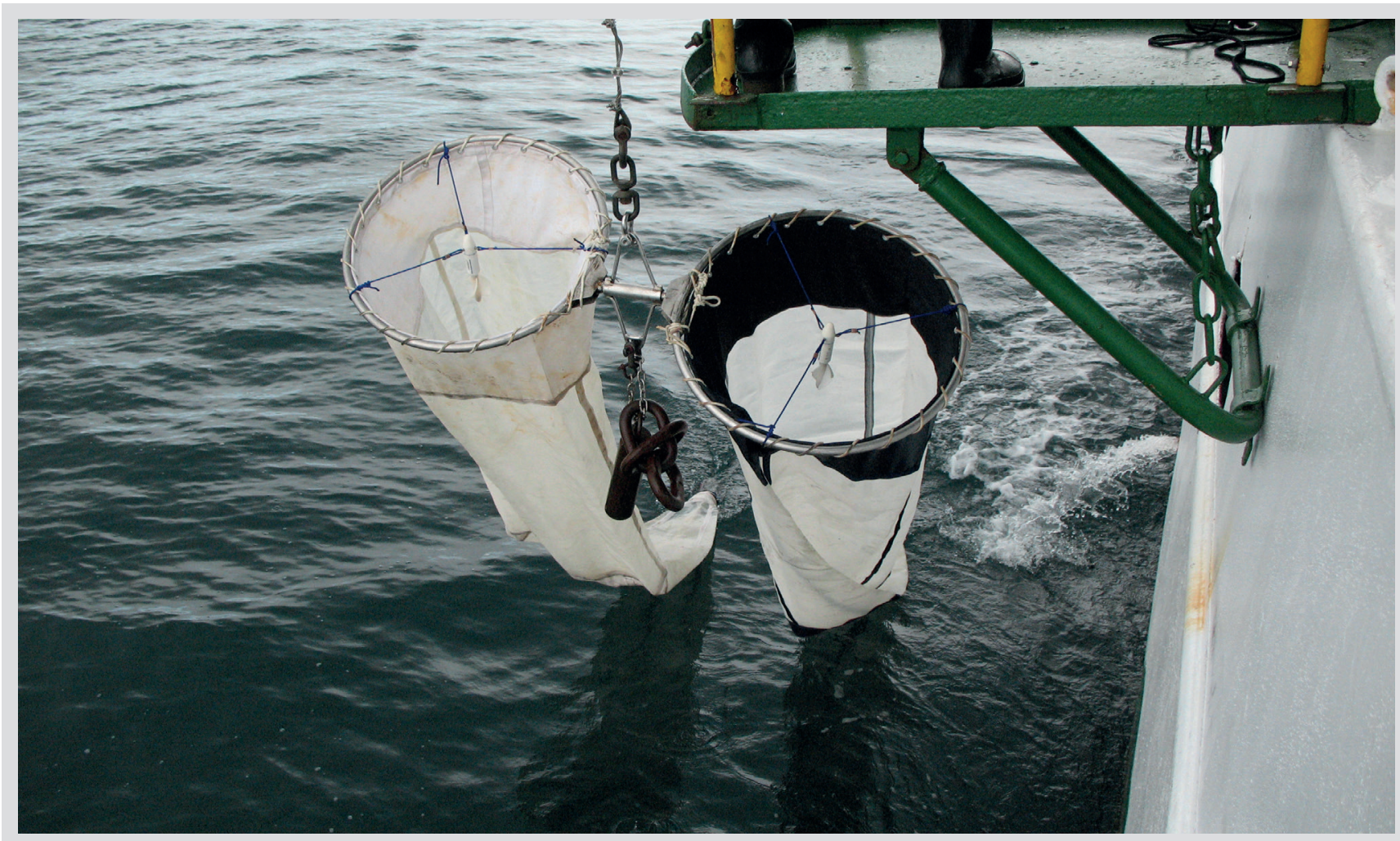

Figura 4. Red de muestreo (Bongo estándar).

Figure 4. Sampling net (standard Bongo).

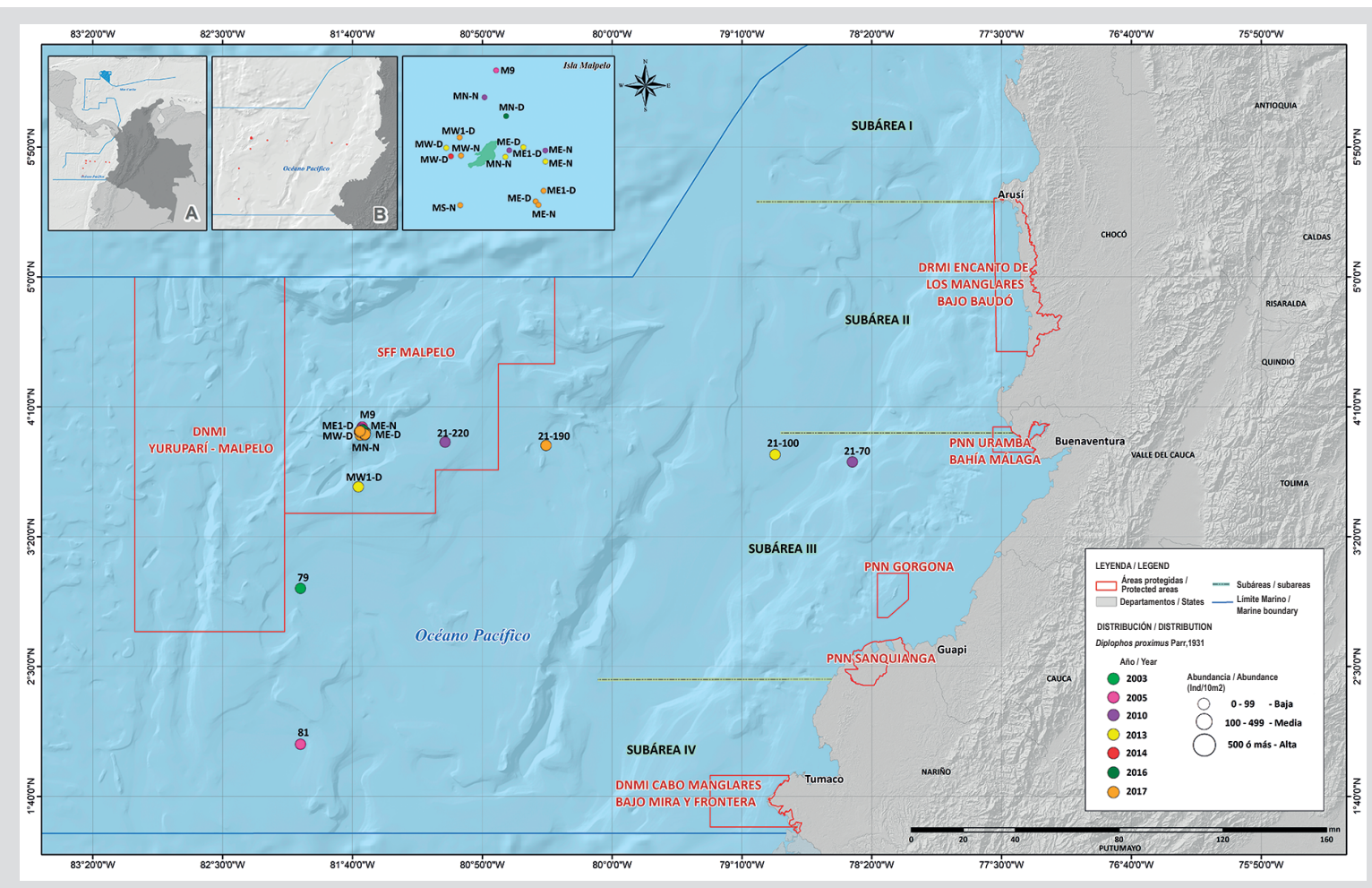

Figura 5. Distribución y abundancia de larvas de Diplophos proximus colectadas entre 2003 y 2017 en el Pacífico colombiano.

Figure 5. Distribution and abundance of Diplophos proximus larvae collected between 2003 and 2017 in the Colombian Pacific. 


\section{RESULTADOS}

Las colectas de las larvas de $D$. proximus se realizaron durante septiembre 2003, septiembre 2005, julio y diciembre 2010, diciembre 2013, febrero-marzo 2014, junio 2016, junio y septiembre 2017, en las subáreas III y IV (Figura 5).

Peces de Luz

Diplophos proximus Parr, 1931 (GONOSTOMATIDAE)

Morfología. PREFLEXIÓN: cuerpo muy alargado con longitud preanal (LpA) 68\% de la longitud estándar (LE); cabeza pequeña $(<20 \% \mathrm{LE})$, ojo redondeado y de tamaño moderado (25-33\% longitud de la cabeza (LC)) y boca grande; membrana completa, aletas pectorales presentes, pero en formación. FLEXIÓN: LpA 64\% LE; cabeza y ojos pequeños $(<25 \%$ LC $)$; aletas dorsales, anal, pectorales y caudal en formación. POSTFLEXIÓN: LpA 62.7\% LE; cabeza y ojo similar al anterior; con dentición en ambas mandíbulas, aleta anal formada. TRANSFORMACIÓN: LpA 56-58\% LE; cabeza pequeña; solo aletas dorsal, anal y caudal formadas, pliegues transversales a lo largo del intestino grueso, 36 miómeros pre anales, 86 miómeros totales (Figura 6).

Pigmentación. PREFLEXIÓN: En el istmo 2 o 3 pigmentos, en el pedúnculo de la aleta pectoral y sobre el ano, series sobre los bordes dorsal y ventral del cuerpo. FLEXIÓN: En la cabeza, laterales al cerebro y en la punta de la mandíbula. Series de pigmentos post anales en parejas o parches en el borde ventral y base de radios. Abundantes sobre el pedúnculo caudal y radios. POSTFLEXIÓN: Similar a la anterior. Dos sobre el ano. TRANSFORMACIÓN: Similar a la anterior, además sobre el cerebro y maxila, serie grande de melanóforos o parches de pigmentos dorsales y ventrales, 20 dorsal, 13 ventral (en la cola), (Figura 6, Tabla 1).

Especies similares. Las larvas de Diplophos taenia se pueden distinguir de las de D. proximus, por poseer mayor número de radios anales (59-72), miómeros (89-99) y pigmentos dorsales y ventrales.

Hábitat. Epi y mesopelágicos. Larvas presentes en las subáreas III y IV entre bahía Málaga y límites con Ecuador entre 130 y $463 \mathrm{~km}$ de la costa; y al norte, este y oeste del SFF Malpelo entre 0.80 y $1.61 \mathrm{~km}$ de la isla (Figura 5).

\section{RESULTS}

The collections of $D$. proximus larvae were carried out during September 2003, September 2005, July and December 2010, December 2013, February-March 2014, June 2016, June and September 2017, in subareas III and IV (Figure 5).

\section{Light fish}

Diplophos proximus Parr, 1931 (GONOSTOMATIDAE)

Morphology. PREFLEXION: very elongated body with a preanal length (LpA) 68\% of the standard length (LS); head small $(<20 \% \mathrm{LS})$, eyes rounded and moderately sized (25-33\% head length (HL)); mouth large; membrane complete; pectoral fins present but in development. FLEXION: LpA 64\% LS; head and eyes small $(<25 \%$ HL); dorsal, anal, pectoral and caudal fins in development. POSTFLEXION: LpA $62.7 \%$ SL; head and eye similar to previous; dentition in both jaws; anal fin developed. TRANSFORMATION: LpA 56-58\% LS; head small; only dorsal, anal and caudal fins developed; transverse folds along the large intestine; 36 pre-anal myomeres; 86 total myomeres (Figure 6).

Pigmentation. PREFLEXION: Two or 3 pigments on isthmus in the peduncle of the pectoral fin and over the anus and in rows on the dorsal and ventral edges of the body. FLEXION: In the head, lateral to the brain and in the tip of the jaw. Rows of post-anal pigments in pairs or patches on the ventral edge and base of the rays. Abundant on the caudal peduncle and rays. POSTFLEXION: Similar to the previous, with two over the anus. TRANSFORMATION: Similar to the previous; over the brain and maxilla, large rows of melanophores or patches of dorsal and ventral pigments, with 20 dorsal and 13 ventral (in the tail), (Figure 6, Table 1).

Similar species. The larvae of $D$. taenia can be distinguished from those of $D$. proximus by a greater number of anal rays (59-72), myomeres (89-99) and dorsal and ventral pigments.

Habitat. Epi and mesopelagic. Larvae present in subareas III and IV between Malaga Bay and the border with Ecuador between 130 and $463 \mathrm{~km}$ from the coast; and to the north, east and west of SFF Malpelo between 0.80 and $1.61 \mathrm{~km}$ from the island (Figure 5). 


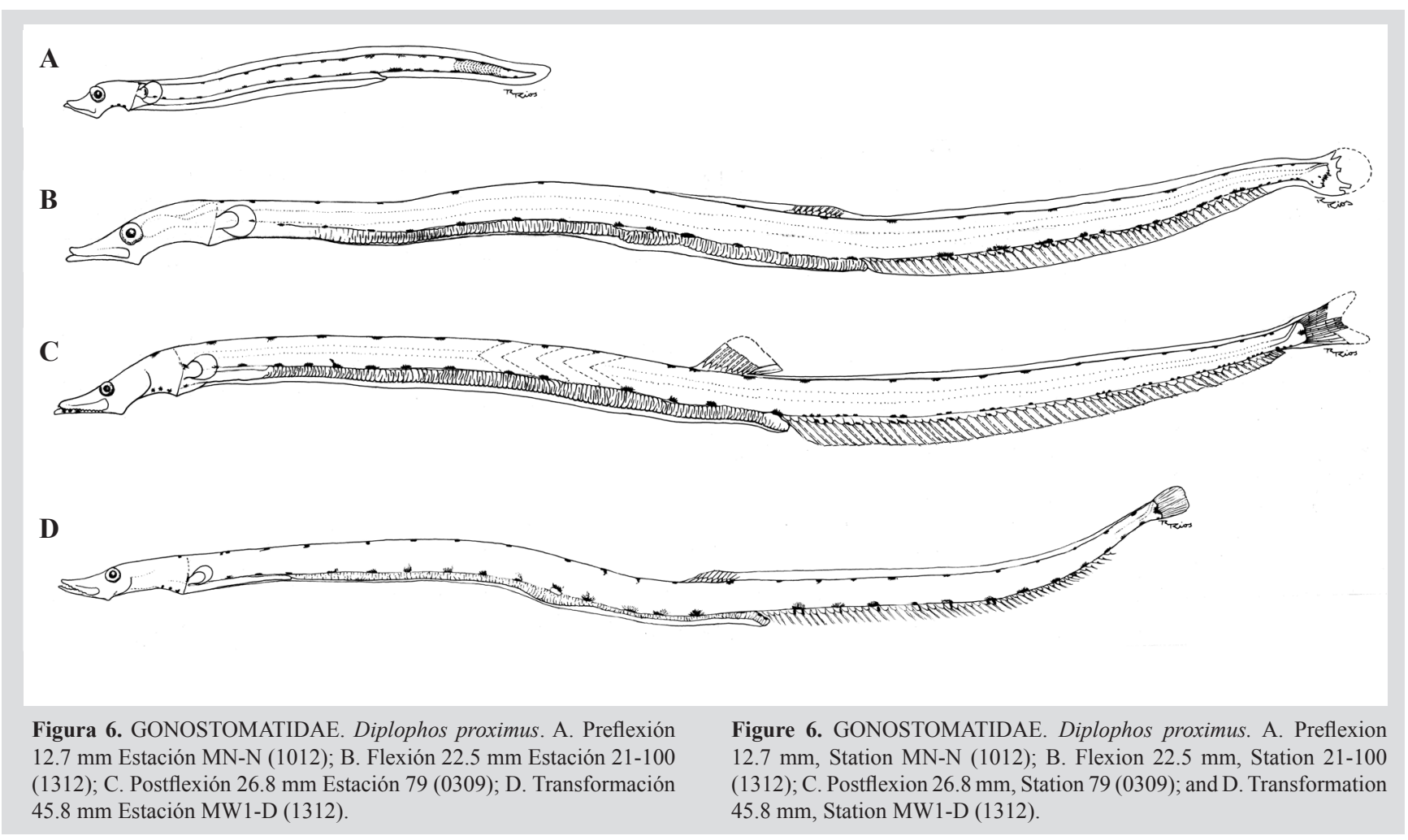

Tabla 1. Merística y morfometría de larvas de Diplophos proximus capturadas en el Pacífico colombiano entre 2003 y 2017. N: Número de individuos revisados; V: Número de vértebras; M: Número de miómeros; D: Aleta dorsal; A: Aleta Anal; Pv: Aleta Pélvica; Pc: Aleta pectoral; C: Aleta caudal; $\mathrm{Rb}$ : Radios branquiostegales; LT: Longitud total; LE: Longitud estándar; *F: Aleta en formación Estación: 1007 (año, mes) ME-N: (Malpelo, Este, noche) MN-N: (Malpelo, Norte, noche); 21-100: (transecto, millas náuticas de la costa), ME1-D: (Malpelo, Este, 1 milla, día). 79: (estación ERFEN), MW-D: (Malpelo, Oeste, día), MW1-D: (Malpelo, Oeste, 1 milla, día).
Table 1. Meristics and morphometrics of Diplophos proximus larvae captured in the Colombian Pacific between 2003 and 2017. N: Number of individuals reviewed; V: Number of vertebrae; M: Number of myomeres; D: Dorsal fin; A: Anal fin; Pv: Pelvic fin; Pc: Pectoral fin; C: Caudal fin; $\mathrm{Rb}$ : Branchiostegal rays; LT: Total length; LS: Standard length; *F: Fin in formation; Station: 1007 (year, month) ME-N: (Malpelo, East, night) MN-N: (Malpelo, North, night); 21-100: (transect, nautical miles from the coast), ME1-D: (Malpelo, East, 1 mile, day); 79: (ERFEN station); MW-D: (Malpelo, West, day); and MW1-D: (Malpelo, West, 1 mile, day).

\begin{tabular}{|c|c|c|c|c|c|c|c|c|c|c|c|c|}
\hline $\begin{array}{c}\text { ESTADIO } \\
\text { Stage }\end{array}$ & $\mathbf{N}$ & $\mathbf{V}$ & $\mathbf{M}$ & $\mathbf{D}$ & $\mathbf{A}$ & $\mathbf{P v}$ & $\mathbf{P c}$ & $\mathbf{C}$ & $\mathbf{R b}$ & LT & $\begin{array}{c}\text { LS } \\
\text { Station }\end{array}$ \\
\hline $\begin{array}{c}\text { Preflexión / } \\
\text { Preflexion }\end{array}$ & 3 & & 86 & - & - & - & - & - & - & $8.3-12.7$ & $8.2-12.6$ & $\begin{array}{c}\text { ME-N 1007; } \\
\text { MN-N 1012 }\end{array}$ \\
$\begin{array}{c}\text { Flexión / Flexion } \\
\text { Postflexión / }\end{array}$ & 2 & & 86 & $* \mathrm{~F}$ & $* \mathrm{~F}$ & $* \mathrm{~F}$ & $* \mathrm{~F}$ & $* \mathrm{~F}$ & - & $22.5-28.5$ & $22.0-27.7$ & $21-1001213 ;$ \\
$\begin{array}{c}\text { Postflexion } \\
\text { Transformación / } \\
\text { Transformation }\end{array}$ & 2 & & $9-10$ & 57 & $* \mathrm{~F}$ & $* \mathrm{~F}$ & $* \mathrm{~F}$ & & $26.8-28.5$ & $26.2-27.2$ & $790309 ;$ \\
$\mathrm{ME1-D} \mathrm{1312}$ \\
\hline
\end{tabular}

Condiciones de captura. Temperatura superficial: 25.3-28. $1^{\circ} \mathrm{C}\left(\mathrm{X}=26.8^{\circ} \mathrm{C}\right)$. Salinidad superficial: $25-34(\mathrm{X}=$ 30.7). Profundidad de muestreo: $1-150 \mathrm{~m}(\mathrm{X}=27.7 \mathrm{~m})$. Distancia de la costa: $130-463 \mathrm{~km}$ y 0.9 a $1.85 \mathrm{~km}$ de la isla Malpelo. Hora: (03:58 - 20:18) cualquiera, con preferencia por la noche y madrugada.

Abundancia. Baja ( $\leq 90$ ind $/ \mathrm{m} 2)$ en el $100 \%$ de las estaciones donde se colectó, estación 79 (22 ind/10 $\left.\mathrm{m}^{2}\right)$
Capture conditions. Surface temperature: 25.3 $28.1^{\circ} \mathrm{C}\left(\mathrm{X}=26.8^{\circ} \mathrm{C}\right)$. Surface salinity: 25-34 $(\mathrm{X}=30.7)$. Sampling depth: 1-150 m $(X=27.7 \mathrm{~m})$. Distance from the coast: $130-463 \mathrm{~km}$ and 0.9 to $1.85 \mathrm{~km}$ from Malpelo Island. Time: (03:58 - 20:18), preferably at night and early morning.

Abundance. Low $(\leq 90 \mathrm{ind} / \mathrm{m} 2)$ in $100 \%$ of the stations where it was collected; station $79\left(22 \mathrm{ind} / 10 \mathrm{~m}^{2}\right)$ 
septiembre de 2003 , estaciones $81\left(6 \mathrm{ind} / 10 \mathrm{~m}^{2}\right)$ y $\mathrm{M} 9$ (12 ind $\left./ 10 \mathrm{~m}^{2}\right)$ septiembre de 2005 , estaciones ME-D (2 ind $\left./ 10 \mathrm{~m}^{2}\right)$ y ME-N $\left(1 \mathrm{ind} / 10 \mathrm{~m}^{2}\right)$ julio de 2010 , estaciones 21 $70\left(2 \mathrm{ind} / 10 \mathrm{~m}^{2}\right), 21-220\left(1 \mathrm{ind} / 10 \mathrm{~m}^{2}\right)$ y MN-N $\left(1 \mathrm{ind} / 10 \mathrm{~m}^{2}\right)$ diciembre de 2010, estaciones 21-100 (2 ind $\left./ 10 \mathrm{~m}^{2}\right)$, ME-N (3 ind $\left./ 10 \mathrm{~m}^{2}\right), \mathrm{MN}-\mathrm{N}\left(4 \mathrm{ind} / 10 \mathrm{~m}^{2}\right), \mathrm{ME} 1-\mathrm{D}\left(2 \mathrm{ind} / 10 \mathrm{~m}^{2}\right)$, MW-D (4 ind $\left./ 10 \mathrm{~m}^{2}\right)$ y MW1-D (2 ind $\left./ 10 \mathrm{~m}^{2}\right)$ diciembre de 2013, estación MW-D (2 ind/10 $\left.\mathrm{m}^{2}\right)$ febrero - marzo de 2014 , estación MN-D (4 ind $\left./ 10 \mathrm{~m}^{2}\right)$ junio de 2016, estaciones 21$190\left(1 \mathrm{ind} / 10 \mathrm{~m}^{2}\right)$, MS-N (2 ind/10 $\left.\mathrm{m}^{2}\right)$, ME-D (2 ind $\left./ 10 \mathrm{~m}^{2}\right)$, Nevera D $\left(2\right.$ ind $\left./ 10 \mathrm{~m}^{2}\right)$ junio de 2017 y estaciones ME-N (3 ind/10 $\left.\mathrm{m}^{2}\right), \mathrm{MW}-\mathrm{N}\left(4 \mathrm{ind} / 10 \mathrm{~m}^{2}\right)$, ME1-D $\left(2 \mathrm{ind} / 10 \mathrm{~m}^{2}\right) \mathrm{y}$ MW1-D $\left(4 \mathrm{ind} / 10 \mathrm{~m}^{2}\right)$ septiembre de 2017 . No se capturaron larvas de esta especie en otros cruceros realizados en fechas diferentes a junio, julio, septiembre, diciembre y febreromarzo, ni en cruceros realizados a menos de $130 \mathrm{~km}$ de la costa. La mayor frecuencia y abundancia se encontró durante los meses de septiembre y diciembre (Figura 5).

Ámbito. Circumglobal en aguas tropicales y templadas, Pacífico oriental tropical al sur de California; siendo este el primer registro para el Pacífico de Colombia. La distribución encontrada para las larvas muestra un ámbito latitudinal entre bahía Málaga $\left(04^{\circ} 00^{\prime}\right.$ Lat. N) y la frontera con Ecuador $\left(01^{\circ} 30^{\prime}\right.$ Lat. N), subáreas III y IV y longitudinal desde $130 \mathrm{~km}$ de la costa $\left(78^{\circ} 27^{\prime} 26,2 \mathrm{~W}\right)$ hasta las aguas circundantes al SFF Malpelo (Figura 5).

\section{DISCUSIÓN}

Las colectas de las larvas de D. proximus, se realizaron durante septiembre 2003, septiembre 2005, julio y diciembre 2010, diciembre 2013, febrero-marzo 2014, junio 2016, junio y septiembre 2017, años que coinciden con épocas después de eventos “El Niño" (junio 2002-marzo 2003, agosto 2004-febrero 2005, agosto 2009-mayo 2010, febrero 2015-junio 2016, diciembre 2016-marzo 2017) y durante "La Niña" (agosto 2010-mayo 2011, julio 2016-noviembre 2016, octubre 2017-febrero 2018) (Golden Gate Weather Services, 2015). Para Colombia la especie se encontró en épocas post niño, normales (dic/13 y feb-mar/14) y Niña y post Niña, patrón diferente al registrado por Funes-Rodríguez et al. (2006) para Baja California Sur, que plantea que D. proximus junto con Diaphus pacificus y Benthosema panamense hicieron parte de un grupo de especies tropicales útiles para distinguir el evento El Niño 1982-84. De igual manera, Avendaño-Ibarra et al. (2003) registran otros taxones demersales y mesopelágicos tropicales
September 2003; stations $81\left(6 \mathrm{ind} / 10 \mathrm{~m}^{2}\right)$ and M9 (12 ind $\left./ 10 \mathrm{~m}^{2}\right)$ in September 2005; stations ME-D (2 ind/10 $\left.\mathrm{m}^{2}\right)$ and ME-N $\left(1 \mathrm{ind} / 10 \mathrm{~m}^{2}\right)$ in July 2010 ; stations 21-70 (2 ind $\left./ 10 \mathrm{~m}^{2}\right), 21-220\left(1 \mathrm{ind} / 10 \mathrm{~m}^{2}\right)$ and MN-N $\left(1 \mathrm{ind} / 10 \mathrm{~m}^{2}\right)$ in December 2010; stations 21-100 (2 ind/10 m²), ME-N (3 ind/10 $\left.\mathrm{m}^{2}\right), \mathrm{MN}-\mathrm{N}\left(4 \mathrm{ind} / 10 \mathrm{~m}^{2)}\right)$, ME1-D $\left(2 \mathrm{ind} / 10 \mathrm{~m}^{2}\right)$, MW-D (4 ind/10 $\left.\mathrm{m}^{2}\right)$ and MW1-D (2 ind/10 $\left.\mathrm{m}^{2}\right)$ December 2013, MW-D station ( 2 ind $/ 10 \mathrm{~m}^{2}$ ) from February to March 2014; station MN-D (4 ind/10 $\left.\mathrm{m}^{2}\right)$ in June 2016; stations 21 $190\left(1 \mathrm{ind} / 10 \mathrm{~m}^{2}\right)$, MS-N (2 ind/10 m²), ME-D (2 ind/10 $\left.\mathrm{m}^{2}\right)$, Nevera D (2 ind/10 $\left.\mathrm{m}^{2}\right)$ in June 2017; and ME-N stations (3 ind/10 $\left.\mathrm{m}^{2}\right)$, MW-N (4 ind/10 $\left.\mathrm{m}^{2}\right)$, ME1-D (2 ind/10 $\left.\mathrm{m}^{2}\right)$ and MW1-D (4 ind/10 $\mathrm{m}^{2}$ ) in September 2017. Larvae of this species were not caught on other cruises occurring on dates other than in June, July, September, December and February-March or on cruises made less than $130 \mathrm{~km}$ from the coast. The highest frequency and abundance were found during the months of September and December (Figure 5).

Range. The range is circumglobal in tropical and temperate waters, and it also ranges to the tropical eastern Pacific in southern California. This record is the first for the Colombian Pacific. The distribution found for the larvae shows a latitudinal range between Málaga Bay $\left(04^{\circ} 00^{\prime} \mathrm{Lat} . \mathrm{N}\right)$ and the border with Ecuador $\left(01^{\circ} 30^{\prime}\right.$ Lat. N) in subareas III and IV and a longitudinal range from $130 \mathrm{~km}$ from the coast $\left(7^{\circ} 27^{\prime} 26.2\right.$ W) to the waters surrounding the SFF Malpelo (Figure 5).

\section{DISCUSSION}

The collections of $D$. proximus larvae were carried out in September 2003, September 2005, July and December 2010, December 2013, February-March 2014, June 2016, June and September 2017, years coinciding with periods after "El Niño" events (i.e., June 2002-March 2003, August 2004-February 2005, August 2009-May 2010, February 2015-June 2016, December 2016-March 2017) and during "La Niña" events (i.e., August 2010-May 2011, July 2016-November 2016, October 2017-February 2018) (Golden Gate Weather Services, 2015). For Colombia, the species was found in post-El Niño periods, normal periods (Dec/13 and Feb-Mar/14) and Niña and postNiña periods. This pattern is different from that recorded by Funes-Rodríguez et al. (2006) for Baja California Sur, who claim that D. proximus together with Diaphus pacificus and Benthosema panamense were part of a group of tropical species useful to distinguish El Niño event of 
importantes como Benthosema panamense, Symphurus williamsi, Diplophos proximus y Cubiceps pauciradiatus, que aportaron $12.2 \%$ de la abundancia total durante el otoño de 2003 para Baja California Sur, coincidiendo con informes previos de éstos durante periodos cálidos y con anomalías positivas de la temperatura superficial del mar (TSM) (FunesRodríguez et al., 1995, 2006).

Diplophos proximus es válida de acuerdo con Ozawa et al. (1990) como endémica en el Pacífico oriental tropical; Fourriére et al. (2016) la registran en los arrecifes del archipiélago de Revillagigedo y áreas cercanas de México. Sin embargo, en muchos casos aún $D$. proximus es considerado una sinonimia de $D$. taenia Günther y aunque es una especie diferente, descrita en su estadio larvario en el Atlas No. 33 de CALCOFI (Moser, 1996), esta información no ha sido incluida en la base de peces FishBase.

\section{CONCLUSIONES}

Dado que para Colombia la especie Diplophos proximus se encontró durante épocas climáticas normales, 'El Niño' y ‘La Niña' y que para Baja California Sur se le registra durante periodos cálidos y con anomalías positivas, se podría concluir que efectivamente la especie hace parte de un grupo de especies tropicales útiles para distinguir el evento "El Niño" en otras latitudes.

El encontrar estadios larvales de Diplophos proximus desde 2003 hasta la fecha con una distribución relativamente amplia en el centro sur del Pacífico colombiano, permite asumir que en esa región debe existir una población de adultos potencialmente reproductivos de la especie.

El hecho de no tener capturas o registros de adultos de las especies de la familia Gonostomatidae y de muchas otras especies de otras familias de hábitats meso y batipelágicos, motiva a realizar estudios más completos y detallados en aguas profundas colombianas.

\section{AGRADECIMIENTOS}

A las tripulaciones de la M/N "María Patricia" en los cruceros al SFF Malpelo y del B/O ARC Providencia de la Armada Nacional, en los Cruceros ERFEN, por su apoyo durante la planificación y ejecución de las campañas de muestreo. A la bióloga Yaneth Morales quien participó en la toma de muestras y la fase de separación en el laboratorio del crucero ERFEN (septiembre 2005) y SFF Malpelo (julio
1982-84. Similarly, Avendaño-Ibarra et al. (2003), recorded other important tropical demersal and mesopelagic taxa, such as Benthosema panamense, Symphurus williamsi, D. proximus and Cubiceps pauciradiatus, which contributed $12.2 \%$ of the total abundance during the fall of 2003 for Baja California Sur and is consistent with previous reports during warm periods with positive sea surface temperature (SST) anomalies (Funes-Rodríguez et al., 1995, 2006).

Ozawa et. al. (1990) reported that D. proximus is valid as endemic in the tropical eastern Pacific, and Fourriére et al. (2016) reported that it occurs in the reefs of the Revillagigedo archipelago and areas nearby Mexico. However, D. proximus is often considered synonymous with $D$. taenia Günther despite being a different species, and it has thus been described in its larval stage in Atlas No. 33 of CalCOFI (Moser, 1996), this information has not been included in the FishBase database.

\section{CONCLUSIONS}

In Colombia, the species $D$. proximus has been found during normal climatic periods and "El Niño" and "La Niña" periods, whereas in Baja California Sur, the species has been recorded during warm periods and periods with positive temperature anomalies; therefore, the species is likely part of a group of tropical species that can be used to distinguish the "El Niño" event in other latitudes.

Larval stages of $D$. proximus have been found from 2003 to the present with a relatively wide distribution in the south-central Colombian Pacific; thus, a population of potentially reproductive adults of the species must inhabit this zone.

Because of the lack of captures or catch records of adults of the species of the family Gonostomatidae as well as many other species of other families of meso and bathypelagic habitats, more complete and detailed studies in colombian deep waters should be conducted.

\section{ACKNOWLEDGEMENTS}

The authors are grateful to the crews of the M/N "María Patricia" on the cruises to the SFF Malpelo and the B/O ARC Providence of the National Navy on the ERFEN Cruises for their support during the planning and execution of the sampling expeditions; the biologist Yaneth Morales, who participated in the sampling and the separation phase in the laboratory by the ERFEN cruise (September 2005) 
y diciembre 2010). Al biólogo Maicol Ramírez (de AG Consultores Ambientales S.A.S.), por su colaboración en la toma de muestras durante diciembre de 2013. Al ecólogo Rodrigo Baos (WWF-Colombia), por su colaboración en la toma de muestras durante febrero de 2014. A los biólogos Pablo Jiménez y Graciela Serna (WWF- Colombia) por su colaboración en la toma de muestras durante junio y septiembre de 2017. A WWF-Colombia quien mediante apoyo financiero (Convenio TP 09), apoyó la toma de muestras y/o fase de separación en el laboratorio del crucero ERFEN de septiembre de 2005. A la Fundación Malpelo por la financiación de los cruceros al SFF Malpelo. A Parques Nacionales por el apoyo financiero para la participación de Y. Morales en los cruceros al SFF Malpelo de julio y diciembre de 2010. A Gustavo Gutiérrez (AG Consultores Ambientales S.A.S), por la financiación en la toma de muestras y/o fase de separación en el laboratorio del crucero de diciembre de 2013. A las entidades participantes en los cruceros y sus respectivos investigadores, por el apoyo brindado. A José Tavera (Universidad del Valle) por el envío de literatura. A Luis Zapata (WWF-Colombia) por la revisión del manuscrito. A Arturo Acero (Universidad Nacional de Colombia sede Caribe) por el apoyo brindado. A Leydi Cuadros (WWFColombia) por la elaboración de los mapas. and SFF Malpelo (July and December 2010); the biologist Maicol Ramírez (of AG Consultores Ambientales S.A.S. (AG Environmental Consultants) for his collaboration in sampling during December 2013; the ecologist Rodrigo Baos (WWF-Colombia) for his collaboration in the sampling during February 2014; the biologists Pablo Jiménez and Graciela Serna (WWF-Colombia) for their collaboration in the sampling during June and September of 2017; WWF-Colombia, who provided financial support (TP 09 Agreement) for the sampling and/or separation phase in the laboratory of the ERFEN cruise of September of 2005; the Malpelo Foundation for financing of the cruises to the SFF Malpelo; the National Parks for providing financial support for the participation of Y. Morales in the cruise to SFF Malpelo in July and December 2010; Gustavo Gutiérrez (AG Consultores Ambientales SAS) for providing financing in the sampling and/or separation phase in the laboratory of the cruise of December 2013; the entities participating in the cruise ships and their respective researchers for providing support; José Tavera (Universidad del Valle) for sending literature; Luis Zapata (WWF-Colombia) for reviewing the manuscript; Arturo Acero (Universidad Nacional de Colombia sede Caribe) for providing support; and Leydi Cuadros (WWF-Colombia) for preparing the maps.

\section{BIBLIOGRAFÍA / LITERATURE CITED}

Ahlstrom, E. H., W. Richards and S. H. Weitzman. 1984. Families Gonostomatidae, Sternoptychidae, and associated stomiiform groups: development and relationships. 184-198. In: Moser, H.G., W. J. Richards, D.M. Cohen, M.P. Fahay, AW. Kendall Jr. and S. L. Richardson (Eds.). Ontogeny and systematics of fishes. Am. Soc. Ichthyol. Herpetol. Spec. Publ., 1.

Avendaño-Ibarra, R., R. De Silva-Dávila, F. Ordóñez-Guillén y G. Vázquez-López. 2003. Composición estacional de larvas de peces frente a Baja California Sur (primavera y otoño de 2003). 413 - 431. En: Gaxiola-Castro G. y R. Durazo (Eds.). Dinámica del ecosistema pelágico frente a Baja California 1997-2007. Diez años de investigaciones mexicanas de la corriente de California. SEMARNAT-INE-CICESE-UABC, México D.F. 501 p.

Beltrán - León, B. S. y R. Ríos. 2000. Estadios tempranos de peces del Pacífico colombiano. Instituto Nacional de Pesca y Acuicultura -INPA- ISBN: 9589356-03-6. Buenaventura. $727 \mathrm{p}$.

Castellanos-Galindo, G.A., E.A. Rubio, B.S. Beltrán-León and C. Baldwin. 2006. Checklist of stomiiform, aulopiform and myctophiform fishes of the Tropical Eastern Pacific. Biota Col., 7(2): 245-262.

Centro Control Contaminación del Pacífico - CCCP. 2004-2007. Planes de ejecución cruceros regionales de investigación oceanográfica (ERFEN) en el Pacífico Sudeste 2004 - 2007. Tumaco. 15 p.

Fourriére, M., H. Reyes-Bonilla, A. Ayala-Bocos, J.A. Ketchum and J.C. Chávez-Comparan. 2016. Checklist and analysis of completeness of the reef fish fauna of the Revillagigedo Archipelago, Mexico. Zootaxa, 4150 (4): 436-466.

Fricke, R. W.N. Eschmeyer and R. van der Laan (Eds.). 2018. Catalog of fishes: Genera, species, references. http://researcharchive.calacademy.org/research/ ichthyology/catalog/fishcatmain.asp 18/04/2018.

Funes-Rodríguez R, R. González-Armas y A. Esquivel-Herrera. 1995. Distribución y composición específica de larvas de peces durante y después de El Niño, en la costa del Pacífico de Baja California Sur (1983-1985). Hidrobiología, 5: 113-125.

Funes-Rodríguez, R., A. Hinojosa-Medina, G. Aceves-Medina, S.P. Jiménez-Rosenberg and A.J. Bautista-Romero. 2006. Influences of El Niño on assemblages of mesopelagic fish larvae along the Pacific coast of Baja California Sur. Fish. Oceanogr., 15 (3): 244-255.

Golden Gate Weather Services, 2015. https:/Eventos de El Niño y La Niña en el siglo XXI. 23/09/2015. 
Moser, G. 1996. The early stages of fishes in the California Current Region. Atlas No. 33. CalCOFI. 1505 p.

Nelson, J. S. 2006. Fishes of the world. Third Edit. Fourth Edition. Wiley, New York. 601 p.

Ozawa, T. and K. Oda. 1986. Early ontogeny and distribution of three species of the gonostomatid genus Diplophos in the western North Pacific. 74-84. In: Ozawa, T. (Ed.). Studies on the oceanic ichthyoplankton in the western North Pacific. Kyushu Univ. Press, Fukuoka.

Ozawa, T., K. Oda and T. Ida. 1990. Systematics and distribution of the Diplophos taenia species complex (Gonostomatidae), with a description of a new species. Jap. J. Ichthyol., 37(2): 98-115.

Prahl, H. v., J.R. Cantera y R. Contreras. 1990. Manglares y hombres del Pacífico colombiano. Fondo FEN, Bogotá. 193 p.

Rueda-Montenegro, C. y B. S. Beltrán-León. 1992. Ictioplancton de las familias Clupeidae y Engraulidae en el litoral Pacífico colombiano. 741-752. En: Mem. VIII Sem. Nal Cienc. Tecnol. Mar Congr. Centroam. Car. Cienc. Mar, Santa Marta.

Smith, L. y S. Richardson. 1979. Técnicas standard para prospecciones de huevos y larvas de peces pelágicos. FAO. Doc. Tec. Pesca, $175: 107$.

Watson, W. 1996. Gonostomatidae: Bristlemouths. 247-267. In: Moser, H.G. (Ed.). The early stages of fishes in the California Current Region. California Cooperative Oceanic Fisheries Investigations (CalCOFI) Atlas No. 33. Allen Press, Inc., Lawrence, Kansas. 1505 p.

Zapata, L. A., G. Rodríguez, B. Beltrán, G. Gómez, W. Angulo, A. Gómez e Y. Morales 1999. Prospección de los principales bancos de pesca en el Pacífico colombiano, durante noviembre de 1998. Bol. Cient. INPA, (6): 111-175 